\title{
Examining the Relation between Social Values Perception and Moral Maturity Level of Folk Dancers
}

\author{
Pınar Karacan Doğan ${ }^{1}$ \\ ${ }^{1}$ Sports Sciences Faculty, Gazi University, Ankara, Turkey \\ Correspondence: Pınar Karacan Doğan, Sports Sciences Faculty, Gazi University, Ankara, Turkey \\ Received: December 23, 2017 \\ Accepted: January 29, 2018 \\ Online Published: January 31, 2018 \\ doi:10.5430/ijhe.v7n1p126 \\ URL: https://doi.org/10.5430/ijhe.v7n1p126
}

\begin{abstract}
The purpose of the present study is to examine the relation between social values perceptions and moral maturity levels of folk dancers, and evaluate this relation in terms of some variables. The relational screening model was used in the study. The "Multi-dimensional Social Values Scale", which was developed by Bolat (2013), and the "Moral Maturity Scale", which was developed by Şengün and Kaya (2007), were used as the data collection tools. The sampling of the study consisted of 251 volunteering individuals who were selected with the Random Selection Technique from among the individuals who participated in Interuniversity Folk Dances Championship in 2016-2017. In the scope of the study, the descriptive statistics were computed for social values perceptions and moral maturity levels of the folk dancers. In evaluating the data of the study, frequencies and percentage distributions were used as statistical method. In addition, the t-test was used for paired groups, the one-way variance analysis (ANOVA) was used for multiple groups, and the Pearson Correlation Analysis was used to detect the relation between the variables. The $p$ value of significance was taken as 0,05 in different tests.

When the findings of the study were examined, it was determined that the social value perceptions and moral maturity levels of the folk dancers who participated in Interuniversity Folk Dances Championship were at a high level, and there was a significant relation in positive direction between the perceptions in all sub-dimensions of the Multi-Dimensional Social Values Scale and the moral maturity levels of the participants. In this context, it is possible to claim that as the moral maturity levels of the folk dancers increase, so do their social values perceptions. When the social value perceptions were analyzed in terms of sub-dimensions, it was determined that the highest perception was in religious values sub-dimension, and the lowest perception was detected in political values. When the findings of the study were analyzed in terms of demographical variables, it was determined that there were significant differences between some of the sub-dimensions of the Social Values Scale and the "gender, the faculty studied at, folk dances experience, income level and the place where the participant spend most of his/her life" variables.
\end{abstract}

Keywords: Folk Dances, Value, Social Value, Morality, Moral Maturity

\section{Introduction}

People acquire the culture of the society in which they live, which is transferred between generations, in socializing process through learning. In this socializing process, "values" appear as a result of the standard criteria of individuals for thoughts, attitudes, behaviors and works, and constitute an indispensable part of social integrity (Yetim, 2010). Values have become a field that is emphasized by health and social sciences in recent years. The reason for this is the changes that appeared in moral decision-making mechanisms of individuals under the influence of today's living conditions (Doğan, 2015).

The value concept is the manner of action or existence accepted by a society or by an individual as the ideal one. Value makes the creatures and behavior patterns become desirable and respected (Doğan, 2012). Value is a behavior style which enables that a society exists and is adopted by great majorities within the society constituting common behavior patterns, and takes its source from education, social, economic, religious, moral and psychological systems (Taşpınar, 2009).

Values are the criteria that are based on the valuation of the importance of a group or a society, people, patterns, targets and other socio-cultural objects (Fichter, 2006). Values emerge in the thoughts, behaviors and works of individuals as certain criteria, and constitute an indispensable element of social integrity. Individuals adopt the values of the group, society and culture in which they live and use them as criteria in their reasoning and choices. 
Individuals thus find the opportunity of making judgments like "better", "more accurate", "more suitable", "more beautiful", "more important" or "fairer" (Tolan, 1991).

Values that show variations according to individuals or societies and that are acquired during the growth period of individuals are at the same time the determinants of the attitudes and behaviors of the individual (Coombs-Richardson \& Tolson, 2005). Every society has specific values, and there are common and universal values for all societies. Among the major ones, there are freedom, democracy, justice, human rights, being industrious, honesty, hospitality, helpfulness, etc. (Bahar, 2005).

The shaping of values in certain time periods and in certain places occurs with the norms. In other words, norms are the concrete forms of values in social life (Aydin, 1991). "Values" rank the first among the most important elements of the structure of social systems. It is possible to define values as "standards" in terms of the attitudes and behaviors of people. Morality and religious values, which have been institutionalized to a certain level, are merged with the attitudes and behaviors of people. Values define the desired things (Dönmezer, 1994). The values formed by humans as a social entity in social life constitute the Social Values. The most prominent characteristics of human is the necessity to live a social life, not a solitary life; and when considered in this respect, Social Values that regulate social life provide an order for the relations between the individual and the society (Güngör, 2008). For this reason, the powers that make the individuals of a society move closer to each other and make them sustain this proximity are "Social Values". Social Values reflect the feelings and opinions of the society. Social values protect the attributes that make humans become real humans and are based on morality principles and moral belief. Respect for goodness, honesty, affection, tolerance, protection and similar spiritual values and devotion to divine values are the basic connectors of the society (Nirun, 1986). In other words, Social Values are the moral beliefs that reflect the common opinions and feelings of the individuals who are the members of the society (Yazic1, 2014).

Social Values are the social powers of the society. Social groups and social institutions carry a lot of values in their essence. Social values gain power at the same rate with the value and extent of the targets of the institutions and groups. Social institutions receive their power from social values like customs, traditions, family, religion, morality, education, science, economy, politics etc. (Yetim, 2010). Based on this point, folk dances that exist in the lives of people in one way or another in different types in the social life (Artun, 2009) contribute to the individual-individual and individual-society communication in the social structure. In closed societies where Traditional Values are dominant, folk dances are used for educational and communicational purposes together with other elements. Through folk dances, various Social Values are transferred to new generations (Sümbül, 1995).

The relation of Social Values with collectivism and practice takes us to their connection with morality, because morality is one of the most important phenomena that show itself in a judgment on what is good and what is bad for an individual (Güngör, 1998).

Morality is the auditing of an individual without the effect of social order rules and somehow having the power of self-control (Usta, 2011). Morality may also be defined as the system of belief and opinions that guide the individual to do the good behaviors and to abstain from the bad ones with his/her own will to reach a goal (Aydin, 2010).

Moral Maturity is defined as the top and most competent level of attitudes, feelings, opinions and behaviors of an individual that are accepted by the society in moral dimensions (Lickona, 1991).

Moral Maturity is defined by the depth and consistency of common sense. In order to accept morality as mature, it is not adequate to have feelings, opinions and judgments; in addition to these, these values must be converted into attitudes and into a conscious of behavior (Fukuyama, 1992).

Kohlberg (1977) examined moral development into periods. Kohlberg examined the reactions of individuals given to certain events as the Pre-Traditional Level in which the rules are set by others; the Traditional Level in which the demands and expectations of the society are considered above all; and the Post-Traditional Level in which the individual sets a value system independently from others and from the authority (Kohlberg, 1977). According to Kohlberg, the majority of people are at the "Traditional Morality Level", which is the second moral development level; and very few people arrive at the third level, which is the highest level and which is named as the Post-Traditional Level. According to Kant, who inspired Kohlberg, on the other hand, reaching to the highest level of moral maturity requires adjusting the actions according to universal principles (Habermas, 1990).

Moral Maturity also requires that moral values are internalized and rooted in the conscious. For moral maturity, it is not adequate to have the moral values as opinions and judgment. Meanwhile, it is also necessary to convert these values into attitudes and behavioral conscious and requires an agreement and consistency in terms of opinions and behaviors. When all these elements become habitual actions, only then, the moral maturity occurs (Fukuyama, 1998). 
When the relevant literature is examined, it is considered that this research will contribute to the science because there is not enough study about social values perception and moral maturity level on folk dancers. In this context this study, the basic problem was to answer the question "Is there a relation between the social values perception and moral maturity of folk dancers?". In addition to this, the moral maturity levels and social value perceptions of folk dancers were examined in terms of some variables.

\section{Method}

\subsection{The Model of the Study}

In the context of the present study, the aim was to examine the relation between social values perceptions and moral maturity levels of folk dancers who study at university. In the context of this aim, the study was designed according to the relational screening model. In the relational screening model, the aim is to determine the existence and the level of the change in the union formed by more than one variable (Karasar, 2012). In the present study, it was also investigated whether the Social Values Perception and Moral Maturity levels of folk dancers varied according to some demographical characteristics of folk dancers.

\subsection{The Population and Sampling of the Study}

The study population consisted of folk dancers who participated in Interuniversities Folk Dances Championship in 2016-2017 academic year. The sampling of the study consisted of 251 volunteering participants who were selected with the random sampling method. In order to determine the number of the sampling, the equation defined by Büyüköztürk et al. (2017) given below was used.

$$
\frac{n_{0}}{1+\frac{n_{0}}{N}}
$$

Equation 1. Estimation of sampling size in continuous variables

In Equation 1, the $\mathrm{n}_{0}=\left(\mathrm{t}^{2} \mathrm{PQ}\right) / \mathrm{d}^{2}$ is used, the $\boldsymbol{p}$ significance value is taken as $0,05, \mathrm{pq}=0,25$, and for this reason, the $t$ value in the table is 1,96; the $\mathrm{n}_{0}=384,16$ is obtained at 0,05 significance level (Büyüköztürk et al., 2017). When the sampling is computed in the study, Equation 2 is obtained when $\mathrm{n}_{0}$ is placed.

$$
=\frac{384,16}{1+\frac{384,16}{722}}=250,74=251
$$

Equation 2. Sampling Size Computation

The distribution of the folk dancers who participated in the study according to their demographical characteristics is given in Table 1.

Table 1. Frequency and Percentage Distribution of the Folk Dancers according to their Demographical

\begin{tabular}{|c|c|c|c|}
\hline & Categories & $f$ & $\%$ \\
\hline \multirow{2}{*}{ Gender } & Female & 131 & 52,2 \\
\hline & Male & 120 & 47,8 \\
\hline \multirow{4}{*}{ Faculty } & Fine Arts Faculty & 45 & 17,9 \\
\hline & Sports Sciences Faculty & 44 & 17,5 \\
\hline & Other Faculties & 162 & 64,5 \\
\hline & $1-2$ & 106 & 42,2 \\
\hline \multirow{3}{*}{ Folk Dances experience } & $3-4$ & 43 & 17,1 \\
\hline & $5-6$ & 41 & 16,3 \\
\hline & 7 and over & 61 & 24,3 \\
\hline \multirow{3}{*}{ Income Level } & Low & 26 & 10,4 \\
\hline & Medium & 168 & 66,9 \\
\hline & High & 57 & 22,7 \\
\hline \multirow{3}{*}{$\begin{array}{l}\text { The Place where the Individual } \\
\text { spent Most of His/Her Life }\end{array}$} & Village-Town-County & 54 & 21,5 \\
\hline & City & 106 & 42,2 \\
\hline & Metropolitan city & 91 & 36,3 \\
\hline Total & & 251 & 100,0 \\
\hline
\end{tabular}
Characteristics 


\subsection{Data Collection Tools}

In the context of the present study, the data were collected with Personal Information Form, Multi-Dimensional Social Values Scale and Moral Maturity Scale from the folk dancers.

\subsubsection{Personal Information Form}

The Personal Information Form was created to determine the data on genders, faculties, folk dances experiences, income levels and the place where the folk dancers spent most of their lives. The Personal Information Form was applied to the participants before the scales.

\subsubsection{Multi-Dimensional Social Values Scale}

In the context of the study, for the purpose of determining the Social Values perceptions of the folk dancers, the "Multi-dimensional Social Values Scale", which was developed by Bolat (2013), was used. The scale has a 5-Point Likert design, and consists of 6 sub-dimensions. There are social value statements consisting of 42 items in these Sub-dimensions. These Sub-dimensions are 1. Family Values Dimension, 2. Scientific Values Dimension, 3. Working-Job Values Dimension, 4. Religious Values Dimension, 5. Traditional Values Dimension, 6. Political Values dimension. The Cronbach Alpha Internal Consistency values computed for the reliability of the Sub-dimensions that constituted the scale were found to be " $0,71,0,73.0,78,0,72,0,70,0,76$ ", respectively.

\subsubsection{Moral Maturity Scale}

The "Moral Maturity Scale", which was developed by Şengün and Kaya (2007), was used in the study to determine the moral maturity levels of the folk dancers whose opinions were received in the context of the study. There are a total of 66 Items in the Moral Maturity Scale, and these Items are ranked in the 5-Point Likert design. The test-half test reliability coefficient of the Moral Maturity Scale was found to be 0,89 ; and the Cronbach Alpha reliability coefficient was 0,93 .

\subsection{The Analysis of the Data}

The data collected with the scales used in the study were analyzed in the SPSS-21 package program. The descriptive statistics were defined in the study (the number of the people, minimum, maximum, average, standard deviation). Then, the skewness and kurtosis coefficients were computed in order to determine whether the data were distributed normally according to the demographical characteristics of the folk dancers, and the histogram graphics were examined. The Pearson Correlation Coefficient was computed to determine the relation between the social values perceptions and moral maturity levels of the folk dancers. About the gender and working status of the folk dancers, the $\boldsymbol{t}$-test was used in determining the difference between the Sub-dimension perception levels of the Multi-Dimensional Social Values Scale; the One-way variance analysis (ANOVA) was used in determining the difference between the perception levels of the folk dancers in Sub-dimensions of the Multi-Dimensional Social Values Scale according to the folk dances experience, faculty, income level, and the place where the folk dancers spend most of their lives. The Tukey test, which is one of the multiple comparison (post hoc) tests in one-way variance analysis, was employed to compare the groups in case significant differences were detected between the variables of more than two groups (Can, 2014). The significance in different tests was taken as $p<0,05$.

\section{Findings}

\subsection{What are the Moral Maturity Levels of the Folk Dancers Who Participated in the Study?}

Table 2. The Descriptive Statistics of the Folk Dancers in Moral Maturity Levels

\begin{tabular}{lccccc}
\hline & $\mathrm{N}$ & Minimum & Maximum & $\bar{X}($ Average $)$ & $\mathrm{S}$ \\
\hline Moral Maturity Scale & 251 & 66,00 & 330,00 & $232,20(3,52)$ & 42,50 \\
\hline
\end{tabular}

Ranges (5-1)/5=0,80 Criterion: 1,00-1,79=Very Low; 1,80-2,59=Low; 2,60-3,39=Medium; 3,40-4,19=High; 4,20-5,00=Very high

When Table 2 is analyzed, it is observed that the moral maturity levels of the folk dancers was high with $\bar{X}=3,52$. 


\subsection{What are the Social Value Perceptions of the Folk Dancers?}

Table 3. The Descriptive Statistics of Folk Dancers that Constitute the Sub-dimensions of the Multi-Dimensional Social Values Scale

\begin{tabular}{lccccc}
\hline Sub-dimensions & N & Minimum & Maximum & $\bar{X}$ (Average) & S \\
\hline Family Values (6 Items) & 251 & 7,00 & 30,00 & $21,09(3,52)$ & 4,89 \\
Scientific Values (6 Items) & 251 & 6,00 & 30,00 & $21,40(3,57)$ & 5,12 \\
Working-Job Values (8 Items) & 251 & 10,00 & 40,00 & $28,19(3,52)$ & 6,73 \\
Religious Values (6 Items) & 251 & 7,00 & 30,00 & $21,69(3,62)$ & 5,51 \\
Traditional Values (6 Items) & 251 & 10,00 & 30,00 & $20,82(3,47)$ & 3,84 \\
Political Values (10 Items) & 251 & 12,00 & 50,00 & $33,98(3,40)$ & 7,21 \\
\hline
\end{tabular}

Ranges (5-1)/5=0,80 Criterion: 1,00-1,79=Very Low; 1,80-2,59=Low; 2,60-3,39=Medium; 3,40-4,19=High; 4,20-5,00=Very high

When Table 3 analyzed, it is observed that the folk dancers whose opinions were asked in the scope of the study had high level average values in all sub-dimensions in value perceptions. The highest value perception of the folk dancers was determined in Religious Values with $\bar{X}=3,62$; and the lowest value perception was determined in political values sub-dimension with $\bar{X}=3,40$.

\subsection{Is there a Relation between the Social Value Perceptions and Moral Maturity Levels of Folk Dancers?}

Table 4. The Pearson Correlation Analysis between the Multi-Dimensional Social Values Scale and Moral Maturity Scale

\begin{tabular}{|c|c|c|c|c|c|c|c|}
\hline & & $\begin{array}{l}\text { Family } \\
\text { Values }\end{array}$ & $\begin{array}{l}\text { Scientific } \\
\text { Values }\end{array}$ & $\begin{array}{l}\text { Working-J } \\
\text { ob Values }\end{array}$ & $\begin{array}{l}\text { Religious } \\
\text { Values }\end{array}$ & $\begin{array}{l}\text { Traditional } \\
\text { Values }\end{array}$ & $\begin{array}{l}\text { Political } \\
\text { Values }\end{array}$ \\
\hline $\mathrm{N}=251$ & & Dimension & Dimension & Dimension & Dimension & Dimension & Dimension \\
\hline Moral Maturity & $\mathrm{r}$ &, $61(* *)$ &, $52(* *)$ &, $56(* *)$ &, $53(* *)$ &, $32(* *)$ &, $51(* *)$ \\
\hline Scale & $\mathrm{p}$ & ,000 & ,000 & ,000 & ,000 & ,000 & ,000 \\
\hline
\end{tabular}

**p $<, 01, * \mathrm{p}<, 05$

When Table 4 is analyzed it is observed that there is a positive relation just above medium significance level between the perceptions of folk dancers in Moral Maturity Levels and Multi-Dimensional Social Values Scale family values sub-dimension at $r=, 61, p=, 000<, 01$. The moral maturity of the folk dancers explain the $37,2 \%\left(r^{2}=0,67 X 0,67=0,372\right)$ of the family values perceptions.

It was observed that there is a positive medium-level significant relation between the perceptions in the sub-dimensions of the scientific values of the Multi-Dimensional Social Values Scale and the folk dancers' Moral Maturity Levels according to $\mathrm{r}=52, \mathrm{p}=, 000<, 01$. The moral maturity of the folk dancers explain $27 \%$ $\left(\mathrm{r}^{2}=0,52 \times 0,52=0,27\right)$ of the scientific values perceptions.

It was observed that there is a positive and significant medium-level relation between the perceptions in scientific values of the Multi-Dimensional Social Values Scale and the Moral Maturity Levels of the folk dancers according to $\mathrm{r}=, 52, \mathrm{p}=, 000<, 01$. The moral maturity of the folk dancers explain $27 \%\left(\mathrm{r}^{2}=0,52 \mathrm{X} 0,52=0,27\right)$ of the scientific values perceptions.

It was observed that there is a positive and significant medium-level relation between the perceptions between the Moral Maturity Levels of the folk dancers and the perceptions in the working-job values sub-dimension of the Multi-Dimensional Social Values Scale according to $\mathrm{r}=, 56, \mathrm{p}=, 000<, 01$. The moral maturity of the Folk dancers explain $31,4 \%\left(\mathrm{r}^{2}=0,56 \times 0,56=0,314\right)$ of the working-job values perceptions.

It was observed that there is a positive and significant medium-level relation between the perceptions of the folk dancers' Moral Maturity Levels and the Religious values sub-dimension of the Multi-Dimensional Social Values Scale according to $r=, 53, p=, 000<, 01$. The moral maturity of the folk dancers explain $28,1 \%\left(r^{2}=0,53 X 0,53=0,281\right)$ of the religious value perceptions.

It was observed that there is a positive and significant relation just above the low level between the perceptions between Moral Maturity Levels and Multi-Dimensional Social Values Scale of the folk dancers according to $\mathrm{r}=, 32$, 
$\mathrm{p}=, 000<, 01$. The moral maturity of the folk dancers explain $10,2 \%\left(\mathrm{r}^{2}=0,32 \mathrm{X} 0,32=0,102\right)$ of the traditional value perceptions.

It was observed that there is a positive and significant relation just above the low level between the perceptions of folk dancers in political values sub-dimension of the Multi-Dimensional Social Values Scale and Moral Maturity Levels according to $r=, 51, p=, 000<, 01$. The moral maturity of the folk dancers explain $26 \%\left(r^{2}=0,51 \times 0,51=0,26\right)$ of the political value perceptions.

3.4 Is There a Significant Difference between the Social Value Perceptions of the FOLK DANCers according to Their Genders?

Table 5. The Distribution of the t-test Results in Multi-Dimensional Social Values Scale according to Gender

\begin{tabular}{lccccccc}
\hline & Gender & $\mathrm{N}$ & $\bar{X}$ & $\mathrm{~S}$ & $\mathrm{t}$ & $\mathrm{sd}$ & $\mathrm{p}$ \\
\hline \multirow{2}{*}{ Family Values Dimension } & Female & 131 & 21,12 & 4,57 &, 10 & 249 &, 918 \\
& Male & 120 & 21,06 & 5,24 &, 10 & & \\
Scientific Values Dimension & Female & 131 & 21,46 & 4,69 & & & \\
& Male & 120 & 21,34 & 5,58 &, 18 & 249 &, 858 \\
Working-Job Values Dimension & Female & 131 & 28,44 & 6,25 & & & \\
& Male & 120 & 27,93 & 7,23 &, 60 & 249 &, 549 \\
Religious Values Dimension & Female & 131 & 21,73 & 5,14 & & & \\
& Male & 120 & 21,66 & 5,90 &, 10 & 249 &, 924 \\
Traditional Values Dimension & Female & 131 & 20,03 & 3,83 & & & \\
& Male & 120 & 21,68 & 3,68 & 3,48 & 249 &, $001^{*}$ \\
Political Values Dimension & Female & 131 & 33,82 & 6,49 & & & \\
& Male & 120 & 34,17 & 7,96 &, 38 & 249 &, 702 \\
\hline
\end{tabular}

$* \mathrm{p}<, 05$

In Table 5, it was questioned whether there is a difference between the perceptions of the folk dancers in the sub-dimensions of the Multi-Dimensional Social Values Scale according to their genders. According to the genders of the folk dancers; it is observed in the table that there is not a significant difference according to $p<, 05$ between the Family Values Dimension, Scientific Values Dimension, Working-Job Values Dimension, Religious Values Dimension and Political Values Dimension. When the Traditional Values Dimension was analyzed it was observed that there is a significant difference between the traditional value perceptions and the genders of the folk dancers according to $\mathrm{t}_{(249)}=3,48, \mathrm{p}=, 001<, 05$. This significant difference stems from the fact that the traditional value Perceptions of the males are higher than those of the females. 
3.5 Is There a Significant Difference between the Social Value Perceptions of the Folk Dancers according to the Faculty in Which They Study?

Table 6. The ANOVA Results of the Folk Dancers in Multi-Dimensional Social Values Scale according to the Faculty in which They Study

\begin{tabular}{|c|c|c|c|c|c|c|c|}
\hline Sub-dimensions & Faculty & $\mathrm{N}$ & $\bar{X}$ & $S$ & $\mathrm{~F}(2-248)$ & $\mathrm{p}$ & $\begin{array}{l}\text { Post Hoc } \\
\text { (Tukey) }\end{array}$ \\
\hline \multirow{3}{*}{$\begin{array}{l}\text { Family Values } \\
\text { Dimension }\end{array}$} & Fine Arts Faculty & 45 & 22,58 & 5,09 & \multirow{3}{*}{2,64} & \multirow{3}{*}{, 074} & \\
\hline & Sports Sciences Faculty & 44 & 20,52 & 5,16 & & & \\
\hline & Other Faculties & 162 & 20,83 & 4,71 & & & \\
\hline \multirow{3}{*}{$\begin{array}{l}\text { Scientific Values } \\
\text { Dimension }\end{array}$} & Fine Arts Faculty & 45 & 22,40 & 5,19 & \multirow{3}{*}{1,08} & \multirow{3}{*}{, 343} & \\
\hline & Sports Sciences Faculty & 44 & 21,00 & 5,40 & & & \\
\hline & Other Faculties & 162 & 21,23 & 5,03 & & & \\
\hline \multirow{3}{*}{$\begin{array}{l}\text { Working-Job Values } \\
\text { Dimension }\end{array}$} & Fine Arts Faculty & 45 & 29,78 & 7,17 & \multirow{3}{*}{1,54} & \multirow{3}{*}{, 216} & \\
\hline & Sports Sciences Faculty & 44 & 27,98 & 7,07 & & & \\
\hline & Other Faculties & 162 & 27,81 & 6,48 & & & \\
\hline \multirow{3}{*}{$\begin{array}{l}\text { Religious Values } \\
\text { Dimension }\end{array}$} & Fine Arts Faculty & 45 & 22,38 & 5,96 & \multirow{3}{*}{,46 } & \multirow{3}{*}{, 632} & \\
\hline & Sports Sciences Faculty & 44 & 21,34 & 5,64 & & & \\
\hline & Other Faculties & 162 & 21,60 & 5,36 & & & \\
\hline \multirow{3}{*}{$\begin{array}{l}\text { Traditional Values } \\
\text { Dimension }\end{array}$} & Fine Arts Faculty & 45 & 20,31 & 4,07 & \multirow{3}{*}{1,09} & \multirow{3}{*}{, 337} & \\
\hline & Sports Sciences Faculty & 44 & 21,50 & 3,88 & & & \\
\hline & Other Faculties & 162 & 20,78 & 3,77 & & & \\
\hline \multirow{3}{*}{$\begin{array}{l}\text { Political Values } \\
\text { Dimension }\end{array}$} & Fine Arts Faculty & 45 & 36,40 & 8,34 & \multirow{3}{*}{3,59} & \multirow{3}{*}{,029* } & \multirow{3}{*}{$1>3$} \\
\hline & Sports Sciences Faculty & 44 & 34,36 & 7,95 & & & \\
\hline & Other Faculties & 162 & 33,21 & 6,53 & & & \\
\hline
\end{tabular}

*p<,05 Categories: Fine Arts Faculty=1; Sports Sciences Faculty=2; Other Faculties=3

In Table 6, it is questioned whether there is a significant difference between the perceptions of the folk dancers in the sub-dimensions of the Multi-Dimensional Social Values Scale according to the faculty in which they study. It is observed in the table that there is no significant difference between the perception levels of the folk dancers according to the faculty in which they study and Family Values, Scientific Values, Working-Job Values, Religious Values and Traditional Values Sub-Dimensions according to $\mathrm{p}<, 05$. It is also observed in the table that there is a significant difference between the political value perceptions of the folk dancers according to the faculty in which they study in Political Values sub-dimension according to $\mathrm{F}_{(2-248)}=3,59, \mathrm{p}=, 029<, 05$. This significant difference stems from the fact that the political value perceptions of the folk dancers studying at Fine Arts Faculties are higher than those studying at other faculties. 
3.6 Is There a Significant Difference between the Social Value Perceptions of the Folk Dancers according to Their Folk Dances Experiences?

Table 7. The ANOVA Results of the Folk Dancers in Multi-Dimensional Social Values Scale according to Folk Dances Experiences

\begin{tabular}{|c|c|c|c|c|c|c|c|}
\hline Sub-dimensions & Folk Dances Experience & $\mathrm{N}$ & $\bar{X}$ & $\mathrm{~S}$ & $\mathrm{~F}(3-247)$ & $\mathrm{p}$ & $\begin{array}{l}\text { Post Hoc } \\
\text { (Tukey) }\end{array}$ \\
\hline & 1-2 Years & 106 & 21,55 & 4,22 & \multirow{4}{*}{1,36} & \multirow{4}{*}{, 257} & \\
\hline Family Values & 3-4 Years & 43 & 19,88 & 5,86 & & & \\
\hline \multirow[t]{3}{*}{ Dimension } & 5-6 Years & 41 & 20,71 & 5,04 & & & \\
\hline & 7 and over Years & 61 & 21,41 & 5,10 & & & \\
\hline & 1-2 Years & 106 & 21,21 & 4,51 & \multirow{4}{*}{1,49} & \multirow{4}{*}{, 218} & \\
\hline Scientific Values & 3-4 Years & 43 & 20,21 & 5,99 & & & \\
\hline \multirow[t]{3}{*}{ Dimension } & 5-6 Years & 41 & 22,20 & 5,04 & & & \\
\hline & 7 and over Years & 61 & 22,05 & 5,45 & & & \\
\hline & 1-2 Years & 106 & 28,35 & 6,00 & \multirow{4}{*}{, 85} & \multirow{4}{*}{,470 } & \\
\hline Working-Job Values & 3-4 Years & 43 & 26,79 & 7,70 & & & \\
\hline \multirow[t]{3}{*}{ Dimension } & 5-6 Years & 41 & 28,24 & 6,70 & & & \\
\hline & 7 and over Years & 61 & 28,87 & 7,23 & & & \\
\hline & 1-2 Years & 106 & 21,85 & 5,26 & \multirow{4}{*}{,32 } & \multirow{4}{*}{,808 } & \\
\hline Religious Values & 3-4 Years & 43 & 21,16 & 5,76 & & & \\
\hline \multirow[t]{3}{*}{ Dimension } & 5-6 Years & 41 & 21,29 & 5,46 & & & \\
\hline & 7 and over Years & 61 & 22,07 & 5,87 & & & \\
\hline & 1-2 Years & 106 & 20,33 & 3,83 & \multirow{4}{*}{1,68} & \multirow{4}{*}{, 171} & \\
\hline Traditional Values & 3-4 Years & 43 & 20,53 & 2,94 & & & \\
\hline \multirow[t]{3}{*}{ Dimension } & 5-6 Years & 41 & 21,71 & 4,33 & & & \\
\hline & 7 and over Years & 61 & 21,28 & 4,02 & & & \\
\hline & 1-2 Years & 106 & 34,25 & 6,33 & \multirow{4}{*}{1,93} & \multirow{4}{*}{, 125} & \\
\hline Political Values & 3-4 Years & 43 & 31,63 & 6,52 & & & \\
\hline \multirow[t]{2}{*}{ Dimension } & 5-6 Years & 41 & 34,61 & 8,11 & & & \\
\hline & 7 and over Years & 61 & 34,75 & 8,26 & & & \\
\hline
\end{tabular}

*p<,05 Categories: 1-2 Years=1; 3-4 Years=2; 5-6 Years $=3 ; 7$ and over Years $=4$

In Table 7, it is questioned whether there is a difference between the perceptions of the folk dancers according to folk dances experiences Sub-dimensions of the Multi-Dimensional Social Values Scale. It is observed in the table that there is a significant difference between the perception levels in Family Values, Scientific Values, Working-Job Values, Religious Values, Traditional Values and Political Values Sub-dimensions according to the folk dances experiences of the players in $p<, 05$ significance level. Although there is no significant difference, the traditional, religious and scientific value perceptions increase as the folk dances experience of the folk dancers increased. 
3.7 Is There a Significant Difference between the Social Value Perceptions of the Folk Dancers according to Their Income Level?

Table 8. The ANOVA Results of the Income Level of the Folk Dancers in Multi-Dimensional Social Values Scale

\begin{tabular}{|c|c|c|c|c|c|c|c|}
\hline Sub-dimensions & Income Level & $\mathrm{N}$ & $\bar{X}$ & S & $F(2-248)$ & $\mathrm{p}$ & $\begin{array}{l}\text { Post Hoc } \\
\text { (Tukey) }\end{array}$ \\
\hline \multirow{3}{*}{ Family Values Dimension } & Alt & 26 & 22,42 & 4,77 & \multirow{3}{*}{2,07} & \multirow{3}{*}{, 129} & \\
\hline & Medium & 168 & 20,67 & 5,02 & & & \\
\hline & High & 57 & 21,72 & 4,46 & & & \\
\hline \multirow{3}{*}{ Scientific Values Dimension } & Alt & 26 & 23,23 & 5,09 & \multirow{3}{*}{2,56} & \multirow{3}{*}{, 079} & \\
\hline & Medium & 168 & 20,96 & 5,11 & & & \\
\hline & High & 57 & 21,88 & 5,03 & & & \\
\hline \multirow{3}{*}{$\begin{array}{l}\text { Working-Job Values } \\
\text { Dimension }\end{array}$} & Alt & 26 & 29,58 & 7,17 & \multirow{3}{*}{1,22} & \multirow{3}{*}{, 297} & \\
\hline & Medium & 168 & 27,74 & 6,73 & & & \\
\hline & High & 57 & 28,88 & 6,49 & & & \\
\hline \multirow{3}{*}{ Religious Values Dimension } & Alt & 26 & 24,12 & 4,77 & \multirow{3}{*}{3,17} & \multirow{3}{*}{, $044^{*}$} & \multirow{3}{*}{$1>2,1>3$} \\
\hline & Medium & 168 & 21,24 & 5,49 & & & \\
\hline & High & 57 & 21,91 & 5,65 & & & \\
\hline \multirow{3}{*}{$\begin{array}{l}\text { Traditional Values } \\
\text { Dimension }\end{array}$} & Alt & 26 & 20,15 & 3,40 & \multirow{3}{*}{2,52} & \multirow{3}{*}{, 083} & \\
\hline & Medium & 168 & 20,60 & 3,88 & & & \\
\hline & High & 57 & 21,79 & 3,83 & & & \\
\hline \multirow{3}{*}{ Political Values Dimension } & Alt & 26 & 35,15 & 6,94 & \multirow{3}{*}{, 54} & \multirow{3}{*}{, 584} & \\
\hline & Medium & 168 & 33,69 & 7,43 & & & \\
\hline & High & 57 & 34,32 & 6,74 & & & \\
\hline
\end{tabular}

*p<,05 Categories: Alt=1; Medium=2; High=3

In Table 8, it is questioned whether there is a significant difference between the perceptions of the folk dancers in the sub-dimensions of the Multi-Dimensional Social Values Scale according to their income level. It is observed that there is no significant difference between the perception levels in the Family Values, Scientific Values, Working-Job Values, Traditional Values and Political Values sub-dimensions of the folk dancers according to their income level $(p<, 05)$. It is also observed that there is a significant difference according to $F_{(2-248)}=3,17, p=, 044<, 05$ between the Religious Value perceptions in terms of their income level in Religious Values sub-dimension. This significant difference stems from the Religious Value Perceptions of the folk dancers from low income level being higher than those from medium and high income level. 
3.8 Is There a Significant Difference between the Social Value Perceptions of the Folk Dancers according to the Place When They Spend Most of Their Lives?

Table 9. The ANOVA Results of the Multi-Dimensional Social Values Scale according to the Place where the Folk Dancers Spend most of Their Lives

\begin{tabular}{|c|c|c|c|c|c|c|c|}
\hline & $\begin{array}{l}\text { The Place where the Folk Dancers } \\
\text { Spend most of Their Lives }\end{array}$ & $\mathrm{N}$ & $\bar{X}$ & $S$ & $\mathrm{~F}(2-248)$ & $\mathrm{p}$ & $\begin{array}{l}\text { Post Hoc } \\
\text { (Tukey) }\end{array}$ \\
\hline \multirow{3}{*}{$\begin{array}{l}\text { Family Values } \\
\text { Dimension }\end{array}$} & Village-Town-County & 54 & 20,78 & 5,43 & & & \\
\hline & City & 106 & 21,42 & 4,95 & ,41 & ,664 & \\
\hline & Metropolitan city-Abroad & 91 & 20,90 & 4,50 & & & \\
\hline \multirow{3}{*}{$\begin{array}{l}\text { Scientific Values } \\
\text { Dimension }\end{array}$} & Village-Town-County & 54 & 21,19 & 5,36 & & & \\
\hline & City & 106 & 21,68 & 5,17 &, 27 & ,766 & \\
\hline & Metropolitan city-Abroad & 91 & 21,21 & 4,96 & & & \\
\hline \multirow{3}{*}{$\begin{array}{l}\text { Working-Job } \\
\text { Values Dimension }\end{array}$} & Village-Town-County & 54 & 27,17 & 7,12 & & & \\
\hline & City & 106 & 28,47 & 6,51 &, 80 & ,452 & \\
\hline & Metropolitan city-Abroad & 91 & 28,47 & 6,75 & & & \\
\hline \multirow{3}{*}{$\begin{array}{l}\text { Religious Values } \\
\text { Dimension }\end{array}$} & Village-Town-County & 54 & 21,52 & 5,61 & & & \\
\hline & City & 106 & 22,17 & 5,41 & ,73 & ,484 & \\
\hline & Metropolitan city-Abroad & 91 & 21,24 & 5,58 & & & \\
\hline \multirow{3}{*}{$\begin{array}{l}\text { Traditional Values } \\
\text { Dimension }\end{array}$} & Village-Town-County & 54 & 20,48 & 3,76 & & & \\
\hline & City & 106 & 20,28 & 3,79 & 3,42 &, $034 *$ & $3>2$ \\
\hline & Metropolitan city-Abroad & 91 & 21,65 & 3,86 & & & \\
\hline \multirow{3}{*}{$\begin{array}{l}\text { Political Values } \\
\text { Dimension }\end{array}$} & Village-Town-County & 54 & 33,06 & 6,84 & & & \\
\hline & City & 106 & 35,00 & 7,52 & 1,86 &, 158 & \\
\hline & Metropolitan city-Abroad & 91 & 33,35 & 6,99 & & & \\
\hline
\end{tabular}

$*_{\mathrm{p}}<, 05$ Categories: Village-Town-County $=1$; City =2; Metropolitan city-Abroad =3

In Table 9, it is questioned whether there is a difference between the perceptions of the folk dancers in the sub-dimensions of the Multi-Dimensional Social Values Scale according to the place where the folk dancers spend most of their lives. It is observed in the table that there is no significant difference between the perception levels of the folk dancers in the sub-dimensions of Family Values, Scientific Values, Working-Job Values, Religious Values and Political Values according to the place where the folk dancers spend most of their lives $(p<, 05)$. It is also observed in the table that there is a significant difference between the traditional value perceptions of the folk dancers in Traditional Values sub-dimension according to the place where the folk dancers spend most of their lives according to $\mathrm{F}_{(2-248)}=3,42, \mathrm{p}=, 034<, 05$. This significant difference stems from the fact that the traditional value perceptions of the folk dancers who spend most of their lives in metropolitan city-abroad being higher than those who spend most of their lives in cities.

\section{Discussion and Result}

In the present study, the purpose was to determine the Social Values perceptions and Moral Maturity Levels of the folk dancers according to some variables, and to examine the relation between the Social Values Perception and Moral Maturity Levels.

When the descriptive statistics given in Table 2 are analyzed in the context of this purpose, it is observed that the Moral Maturity Levels of the folk dancers are high with $\bar{X}=3,52$. Çekin (2013) conducted a study on Moral Maturity Levels of the teacher candidates, it was determined that the average of the Moral Maturity Levels of the teacher candidates was 4,26; and it was determined that the same average value was high with 3,94 in a study conducted by Kaya and Aydin (2011) on university students to determine the average of the Moral Maturity Levels. These results are parallel with the results of the present study.

When the studies were examined in the literature that included different study populations, it was observed that Moral Maturity Levels were high, which is similar to the results of the present study (Yüksel, 2012; Şengün, 2013; Demir Çelebi \& Sezgin, 2015). 
According to the results of the present study, folk dancers approach at a highly positive level to the Social Values components. It was also determined in the present study that the average of the scores of the participants in Social Values Perception was high at all sub-dimensions (Table 3).

Altunay and Yalçınkaya (2011) conducted a study and reported that the teacher candidates considered all value fields significant at a high level. The average values obtained in the whole of the scale used in this study being high shows that teacher candidates adopted the value field at a high level. In another study, it was determined according to the viewpoints of the teacher candidates that the primary values that guided the lives of teacher candidates were spiritual values, material/economic values, religious values, cultural values and social values (Yazar, 2012).

As it may be understood from these results, education is one of the most important factors in developing and transferring Morality and Values to new generations. Good morality and values of individuals define the attitudes and behaviors of them, their interactions with the environment, and for this reason, their viewpoints (Dikmen, 2014). It in interesting in the results of the relevant literature that are conducted on university students and teacher candidates that the Social Value and Moral Maturity Levels are high, which shows the importance of education in this context.

When Social Values Scale Sub-dimensions are examined in detail, the highest value perception is religious values with a rate of 3,62, and the lowest value perception was determined in political values with a rate of 3,40 . In the scope of these findings, it was determined that Religious Values and Scientific Values are more dominant (Table 3).

Şahin (2010) conducted a study and determined that the primary values of elementary teacher candidates in social value preferences were the Religious and Morality Values. Bolat (2011) conducted a study and reported that the viewpoints of vocational high school students were at the highest level in "Religious Values" dimension with a rate of 4.28 among Social Values dimensions when compared with the other sub-dimensions; and the viewpoints in "political values" dimension had the lowest average value (3.58). These results support the findings of the present study. As it is well-known, the roots of folklore are based on religious and traditional principles. Religion influences culture, and culture influences religion in a reciprocal manner (Nirun, 1986). Folk dances, which is one of the indispensable elements of culture, is among the "carriers" of religion, like it is the case in many social events. When considered in this context, the high perception levels of folk dancers in Religious Values dimension may be evaluated as an expected result.

When the findings of the study are analyzed, it is observed that there is a significant and positive relation between the Moral Maturity Levels of the folk dancers and all the sub-dimensions of the Multi-Dimensional Social Values Scale (Table 4). Values are the indicators of the ideal ego of the society. Devotion to these values contributes to the formation of the traditions. A culture will only exist when it consists of values. Such a culture is based on hypotheses like respect for the reality, rightness, personal integrity, and love. The culture of values is the integrity of a system based on ethical understanding. The thing that makes a phenomenon, a formation and an event meaningful is the value of it. Value is a criterion for judgments. This criterion is the power of separating the good from the evil, the truth from the wrong, and the good from the bad (Güler, 2008). According to Wienpahl (1948), morality is the action of an individual according to his/her tendencies, and the appearance of behaviors as a result of the tendencies. In addition to this, the morality theory contains the true, the wrong, the good and the bad judgments. Furthermore, the morality theory may also be defined as the working of the good and bad behaviors. These judgments refer to the tendencies of the individual (Narrated by Coşkun, 2009). When the fact that value is also a judgment criterion is considered, Value and Morality appear before us as a whole consisting of two elements that supplement each other. The results of the study support this integrity.

When the t-test results of the participants in Multi-Dimensional Social Values Scale were analyzed according to the gender variable, it was determined that there is a significant difference in traditional value perceptions according to $\mathrm{t}_{(249)}=3,48, \mathrm{p}=, 001<, 05$. This significant difference stems from the high scores of male participants. No significant differences were detected in other dimensions (Table 5).

In the relevant literature, there are different results on the effect of the gender variable on Social Values perception. Turan and Aktan (2008) reported that the Social Values that were considered to exist in school life did not show any variations for female and male students and for teachers, which supports the findings of the present study. Bolat (2011) conducted a study on vocational high school students, and found out that the perceptions of the females in traditional values sub-dimension were at higher levels when compared with those of the males. On the other hand, in the study conducted by Canpolat, Kaya and Kuçuktag (2010), it was reported that spiritual values were adopted more by female teacher candidates than the male teacher candidates. 
It was observed in the study that there were no significant differences between the Social Values Scale, Family Values, Scientific Values, Working-Job Values, Religious Values and Traditional Values Sub-dimensions according to the faculty in which the participants studied. In the Political Values sub-dimension, it was determined that the participants from Fine Arts and Sports Sciences Faculty had higher average values, and thus, created a significant difference (Table 6).

In nearly all of the studies conducted on Politics Science, education and school types are the major Socio-economic factors that play roles in political participation (Şahin, 2013). In this context, higher educational institutions create a specific political culture in their bodies, and this culture might have been influential in obtaining these results. As Holbrook and Garand (1996) emphasized, the group-close relatives and friends which surround the individual affect political behaviors by showing an integrative and encouraging effect for the values of the individual and the values of the group.

In addition, it was emphasized in the relevant literature that individuals dealing with art have an attitude towards politicians, and acquire a certain type of political conscious. Those who see the autonomy of art over the relation between the artist and his/her works claim that art is an expression of liberty and resistance (Bozdağ, 2016). In this way, since the opinions imposed by the government owners for artists do not reflect the inner voice of the artists, they have an opposing attitude towards artistic autonomy and create a higher political value in them when compared with the other layers and the society (Hauser, 1984; Kreft, 2008).

According to the data obtained in the study, no significant differences were detected between the perceptions about the Sub-dimensions of the Multi-Dimensional Social Values Scale according to the experiences of the folk dancers (Table 7). In other words, the Social Values perceptions of the participants who have experiences at different categories are similar. These results might stem from the fact that the participants are from upper-level folk dancers, and based on this, their attitudes towards folk dances and culture are similar.

According to the data obtained in the study, it was determined that there is a significant difference between the Religious Value perceptions of the folk dancers and their income levels variable according to $F_{(2-248)}=3,17$, $\mathrm{p}=, 044<, 05$. This significant difference stems from the fact that the folk dancers from low income levels have higher Religious Value perceptions than those from medium and high income levels. On the other hand, no significant difference was detected in the other dimensions of the Social Values Scale (Table 8). In other words, it is possible to claim according to the study results that as the income levels decrease, the Religious Value Perceptions increase.

The relevant literature supports this situation. According to Macit (2014), when the fact that the religion is an important component of the meaning-belief system of humans is considered, it is emphasized that the poor seek refuge and application in religion to lessen the damaging effects of poverty on their honors. In addition, Marx (1987) defined the religion as the "opium of the masses", and claimed that religion had become the ideological driving force of "staying poor" by legalizing the poor conditions and by encouraging the poor that the return of the stresses and troubles of this world would be received in the hereafter.

It was also determined according to "the place where the folk dancers spend most of their lives" variable in the present study that the folk dancers who were included in the present study had significant differences only in Traditional Values sub-dimension in favor of those who lived in metropolitan cities (Table 9). It was determined that the "place lived in" variable in the study was partly influential on the Social Values Perceptions of the participants. In the relevant literature, different results were reported about the effect of "the place where the folk dancers spend most of their lives" variable on Social Values. Dilmaç et al. (2008) conducted a study and reported that the value perceptions averages of the teacher candidates who grew up in different residential areas differed only in traditional value perception sub-dimension. This result is parallel to the findings of the present study. On the other hand, Bolat (2011) conducted a study in high school students and reported that there was a significant difference in all dimensions of the Social Values Scale (Family Values, Scientific Values, Working-Job Values, Religious Values, Traditional Values, Political Values) according to the residential area variable.

As a consequence, it was determined that the perceptions of folk dancers about Moral Maturity Levels and Social Values were at high levels. In terms of Sub-dimensions, the highest perception scores were detected in Religious Values, and the lowest scores were detected in Political Values dimension. In the present study, it was also determined that there is a positive and significant relation between the perceptions of the participants in Moral Maturity Levels and all the Sub-dimensions of the Multi-Dimensional Social Values Scale. In this context, as the Moral Maturity Levels of the folk dancers increase, so do the Social Value perceptions. When considered in terms of demographical variables, it was determined that there are significant differences between some of the 
sub-dimensions of the Social Values Scale according to gender, the faculty studied at, folk dances experience, income levels and the place where the folk dancers spend most of their lives variables.

\section{References}

Altunay, E., \& Yalçınkaya, M. (2011). Öğretmen adaylarının bilgi toplumunda değerlere ilişkin görüşlerinin bazı değişkenler açısından incelenmesi. Kuram ve Uygulamada Eğitim Yönetimi, 1(1), 5-28. Retrieved from http://dergipark.ulakbim.gov.tr/kuey/article/view/5000050530/5000047788

Artun, E. (2009). Türk Halkbilimi. 5. Bask1. İstanbul: Kitabevi.

Aydın, M. (1991). İlk dönem İslam toplumunun şekillenişi. İstanbul: Pınar.

Aydın, M. Z. (2010). Ailede ahlak eğitimi. İstanbul: Timaş.

Bahar, H. İ. (2005). Sosyoloji. Ankara: Siyasal.

Bolat, Y. (2011). Gazi Üniversitesi meslek yüksek okulu ögrrencilerinin sosyal değerlere baklşları. Doktora Tezi. Gazi Üniversitesi Eğitim bilimleri Enstitüsü, Ankara.

Bolat, Y. (2013). Bir değer ölçme aracı: çok boyutlu sosyal değerler ölçeği. Turkish Journal of Education, 2(4), 13-27. https://doi.org/10.19128/turje.181067

Bozdağ, L. (2016). Çağdaş sanat ve siyaset dönüşümüne yeniden bakmak "politikanın estetize hali". Eğitim Bilim Toplum, 13(52), 94-127. Retrieved from http://egitimsen.org.tr/wp-content/uploads/2015/12/Çağdaş-Sanat-ve-Siyaset-Dönüşümüne-Yeniden-Bakmak-P olitikanın-Estetize-Hali_Lütfiye-Bozdağ.pdf

Büyüköztürk, Ş., Çakmak, E. K., Akgün, Ö. E., Karadeniz, Ş., \& Demirel, F. (2017). Bilimsel araştırma yöntemleri. Ankara: Pegem Akademi. https://doi.org/10.14527/9789944919289

Can, A. (2014). SPSS ile bilimsel araştırma sürecinde nicel veri analizi (2. Bask1). Ankara: Pegem.

Canpolat, E., Kaya, M. \& Küçüktağ, İ. (2010). Öğretmen adaylarının değer algısı. 9. Sinıf Öğretmenliği Eğitimi Sетроzуити, Elazı̆g, 1123-1126.

Coombs-Richardson, R. \& Tolson H. (2005). A comparison of values rankings for selected American and Australian teachers. Journal of Research in International Education, 4, 263-277. https://doi.org/10.1177/1475240905057805

Coşkun, Y., \& Yıldırım, A. (2009). Üniversite öğrencilerinin değer düzeylerinin bazı değişkenler açısından incelenmesi. Yüzüncü Yll Üniversitesi, Eğitim Fakültesi Dergisi, V1(1), 311-328. Retrieved from http://dergipark.ulakbim.gov.tr/yyuefd/article/viewFile/5000055569/5000052873

Çekin, A. (2013). Öğretmen adaylarının ahlaki olgunluk düzeyleri. Kastamonu Eğitim Dergisi, 21(3), 1035-1048. Retrieved from http://79.123.169.199/ojs/index.php/Kefdergi/article/view/22/21

Demir Çelebi, Ç., \& Sezgin, O. (2015). Lise öğrencilerinin öznel iyi oluşları ile ahlâkî olgunluk seviyeleri arasındaki ilişkinin incelenmesi. Kalem Ĕ̈itim ve Insan Bilimleri Dergisi, 5(2), 99-146. https://doi.org/10.23863/kalem.2017.53

Dikmen, F. (2014). Ahlak, değerler ve eğitimi, Prof. Dr. Recep Kaymakcan, Yrd. Doç. Dr. Hasan Meydan Dem Yay., İstanbul, 2014 (Kitap tanıtımı). BEÜ İlahiyat Fakültesi Dergisi, 1(2), 167-174. Retrieved from http://dergipark.ulakbim.gov.tr/beuifd/article/viewFile/5000087091/5000080992

Doğan, İ. (2012). Sosyoloji kavramlar ve sorunlar, Ankara: Pegem Akademi.

Doğan, İ. (2015). Beden eğitimi dersinin öğrenciye kazandırdı̆̆ı değerlerin çeşitli değişkenler açısından incelenmesi. Doktora Tezi. Gazi Üniversitesi Eğitim Bilimleri Enstitüsü, Ankara.

Dönmezer, S. (1994). Toplumbilim. İstanbul: Beta.

Fichter, J. (2006). Sosyoloji nedir. Çev: Nilgün Ç., Ankara: Anı.

Fukuyama, F. (1992). Tarihin sonu ve son insan. Çev. Zülfü D., İstanbul: Simavi.

Fukuyama, F. (1998). Güven: sosyal erdemler ve refahın yaratılması. Çev. Ahmet B., Ankara: TïB.

Güler, A. (2008). Türk toplumunda korku kültürü. Ankara: Punto Tasarım.

Güngör, E. (1998). Değerler psikolojisi üzerine araşttrmalar. İstanbul: Ötüken.

Güngör, E. (2008). Ahlak Psikolojisi ve Sosyal Ahlak. İstanbul: Ötüken. 
Habermas, J. (1990). Moral consciousness and communicative action. MIT press.

Hauser, A., (1984). Sanatın Toplumsal Tarihi, Çev: Y. Gönülü, İstanbul: Remzi Kitabevi.

Holbrook, T., \& Garand, J. C. (1996). Homo economus? Economic information and economic voting. Political Research Quarterly, 49(2), 351-375. https://doi.org/10.1177/106591299604900206

Karasar, N. (2012). Bilimsel araştırma yöntemi, Ankara: Nobel.

Kaya, M., \& Aydın, C. (2011). Üniversite öğrencilerinin dini inanç ile ahlaki olgunluk düzeyleri arasındaki ilişkinin incelenmesi. Ondokuz Mayls Üniversitesi Ilahiyat Fakültesi Dergisi, 30, 15-42. Retrieved from http://dergipark.gov.tr/download/article-file/188445

Kohlberg, L. (1977). The implications of moral stages for adult education. Religious Education, 72(2), 183-201. https://doi.org/10.1080/0034408770720209

Kreft, L., (2008). Sanat ve Siyaset: Sanatın Siyaseti ve Siyasetin Sanatı. Sanat/Siyaset, Ed. A. Artun, İstanbul: İletişim.

Lickona, T. (1991). Educating for character: how our schools can teach respect and responsibility. New York: Bantam Books.

Macit, M. (2014). Yoksulluk, insan onuru ve din. Atatürk Üniversitesi İlâhiyât Tetkikleri Dergisi, 41, 101-116. Retrieved from http://e-dergi.atauni.edu.tr/atauniilah/article/viewFile/5000039921/5000038810

Marx, K., \& Engels, F. (1987). On Religion. Ed. R. Bocock \& K. Thompson, Religion and Ideology, Manchester: Manchester University Press, 11-12.

Nirun, N. (1986). Sosyoloji. İstanbul: MEGSB.

Sümbül, M. (1995). Adana halk oyunlarının sistematik analizi. Yüksek Lisans Tezi, Ankara Üniversitesi Sosyal Bilimler Enstitüsü, Ankara.

Şahin, D. (2010). Sınıf öğretmeni adaylarının toplumsal değer tercihleri: Gazi Üniversitesi, Gazi Eğitim Fakültesi Örneği. 9. Sinıf Öğretmenliği Ĕ̆itimi Sempozyumu, Elazığ, 545-548.

Şahin, M. Y. (2013). Attitudes of academicians in schools of physical education and sports towards political participation: a relational study. Life Science Journal, 10(4): 556-564. Retrieved from https://s3.amazonaws.com/academia.edu.documents/32952582/Attitudes.pdf?AWSAccessKeyId=AKIAIWOW YYGZ2Y53UL3A\&Expires=1517145579\&Signature=YPDnTr1mUum7\%2B5ziZt5tj8sS7\%2Fs\%3D\&respons e-content-disposition=inline\%3B\%20filename\%3DAttitudes_of_Academicians_in_Schools_of.pdf

Şengün, M. (2013). Anne-baba tutumuna göre lise öğrencilerinin ahlâki olgunluk düzeyleri. Hitit Üniversitesi İlahiyat Fakültesi Dergisi, 12(23), 203-215. https://doi.org/10.14395/jdiv60

Şengün, M., \& Kaya, M. (2007). Ahlaki olgunluk ölçeği: geçerlik ve güvenirlik çalışması. Ondokuz Mayls Üniversitesi İlahiyat Fakültesi Dergisi, 24(24-25), 51-64. Retrieved from http://dergipark.gov.tr/download/article-file/188495

Taşpınar, M. (2009). Eğitimde örtük program ve değerler eğitimi, I. Ulusal İyilik Sempozyumu Bildiri Kitabı, 25-30.

Tolan, B. (1991). Toplum bilimlerine giriş. Ankara: Adım.

Turan, S., \& Aktan, D. (2008). Okul hayatında var olan ve olması düşünülen sosyal değerler. Journal of Turkish Educational Sciences, 6(2), 227-259. Retrieved from http://dergipark.gov.tr/download/article-file/256318

Usta, A. (2011). Kuramdan uygulamaya kamu yönetiminde etik ve ahlak. Kahramanmaraş Sütçü İmam Üniversitesi Íktisadi ve İdari Bilimler Fakültesi Dergisi, 1(2), 39-50. Retrieved from http://dergipark.ulakbim.gov.tr/ksuiibf/article/viewFile/5000039244/5000038117

Yazar, T. (2012). Öğretmen adaylarının değerler hakkındaki görüşleri. Pegem Eğitim ve Öğretim Dergisi, 2(1), 61-68. https://doi.org/10.14527/C2S1M6

Yazıcı, M. (2014). Değerler ve toplumsal yapıda sosyal değerlerin yeri. Firat Üniversitesi Sosyal Bilimler Dergisi, 24(1), 209-223. Retrieved from http://dergipark.ulakbim.gov.tr/firatsbed/article/viewFile/5000172957/5000155981

Yetim, A. (2010). Sosyoloji ve spor. Ankara: Berikan.

Yüksel, G. (2012). İlköğretim öğretmenlerinin karakter eğitimi yetkinlik inançları ile ahlaki olgunluk düzeyleri arasındaki ilişki. Yüksek Lisans Tezi. Osmangazi Üniversitesi, Eğitim Bilimleri Enstitüsü, Eskişehir. 